\title{
The Integrative Nature of BE Teaching: Knowledge and Skills
}

\author{
Tingting Guo \\ School of English for International Business \\ Guangdong University of Foreign Studies (GDUFS) \\ No.2, North Baiyun Avenue, Guangzhou 510420, China \\ Wenzhong Zhu \\ School of English for International Business \\ Guangdong University of Foreign Studies (GDUFS) \\ No.2, North Baiyun Avenue, Guangzhou 510420, China \\ Tel: 86-20-3631-7183 E-mail: wenzhong8988@sina.com
}

The research is a partial achievement for the Innovation Research Program "Research on the Approach and Practice for the Teaching of Business English” sponsored by Guangdong University of Foreign Studies (2006-TB-013).

\begin{abstract}
With the great development of the international trade and communication after China's entry into the WTO, the demand for talents qualified in both English and business is increasing, so more universities or colleges have paid their attention to the fostering and cultivation of business talents. Starting with the status quo of the market need for BE (Business English) talents and the required knowledge and skills for them, this paper intends to explore effective BE teaching ways from the perspectives of teachers' qualifications, course designs, teaching models and teaching methodologies.
\end{abstract}

Keywords: Business English teaching, Knowledge, Skill

\section{Introduction}

With the speedup of globalization and opening up, business exchanges are carried out more frequently nowadays, which leads to an increasing demand for talents qualified in both English and business. As a new product of market, Business English has already gained academic endeavor and social recognition and has been taught as a major in many universities or colleges in China in the aim of meeting the need for BE talents over two decades(Zhang Wubao, 2008).

Business English is not only a highly integrated but also quite a strong application-oriented discipline, so it requires the students to be equipped with not only business-related know-how and foreign language knowledge, but also highly practical skills in proficiency and communication. However, the fact is that the development of BE teaching in universities has been far behind the economic development. Thus it is an urgent task for many universities to strengthen and improve the $\mathrm{BE}$ teaching to train more such talents able to do international business directly in English rather than via translators. Therefore, the essential nature of $\mathrm{BE}$ teaching is the integration of knowledge and skills.

This paper intends to explore effective BE teaching methods from the perspectives of market need, teachers' qualifications, course designs and teaching methodologies so as to improve the development of business English teaching.

\section{The Market Niche of BE Talents}

\subsection{The status quo of market need for BE talents}

Since China's entry into WTO, a number of multinational companies and foreign-funded enterprises, especially the top 500 international companies, have come into the Chinese market. Many of them, specialized in various fields like manufacture, trade, agriculture, infrastructure, finance, insurance, accounting, law, medicine, education, transportation and other industries, have achieved a sound development. With the success in multinational marketing goes on, their 
needs for the International BE talents are increasing day after day. However, the fact is that many of the BE graduates lack of either the language and professional knowledge or the practical skills required in business activities. And the world consulting giant McKinsey believes that currently only $10 \%$ of the Chinese university students are in line with the requirements of multinational companies. Therefore, up to now, there still has been an increasing demand for the $\mathrm{BE}$ talents and a great market niche for BE professionals still exists.

\subsection{Knowledge and skills required}

To be a BE talent, not only the basic language and business knowledge but also certain managerial and other practical skills are required. As a language used in business environment, the conception of BE is expanding with the sustainable deepening of business interaction and integration. According to BE expert Nick Brieger from UK, BE teaching should include the English language knowledge, communication skills, expertise, management skills and cultural background. Apart from those requirements, some other skills are needed, such as presentation, team-working, motivation, negotiation, and computer skills, etc. Moreover, it is also necessary for BE students to master the basic knowledge on economics, management, law, statistics, marketing, financing, accounting, and so on. As a result, BE teaching should not only follow the laws of general pedagogy, psychology, linguistics (especially the applied linguistics), but also serve to meet the specific business needs, so it is different from General English (GE) teaching.

\section{BE Teachers' Qualifications}

Since there's great difference between GE teaching and BE teaching, which will require the BE teachers to be more qualified with both language and business knowledge and skills. However, nowadays most BE teachers in universities or colleges, who have got solid language knowledge and skills, used to be GE teachers or with GE backgrounds (Zhang Wubao, 2008), but most of them lack of business background knowledge or skills. Thus it is really an urgent task to train the BE teachers with both language knowledge and practical business skills. To be an excellent BE teacher, what qualifications are required on earth? Then let's have a look.

\subsection{Recognition and Motivation}

In the classes, a BE teacher should remind the students of the significance of motivation to be a successful manager and immediate oral recognition should be frequently given to the students to motivate them as well. Furthermore, the teachers are subject to teach the students various ways to motivate and encourage them to put this motivation skill into practice.

\subsection{Suitable Learning Tasks and Goals}

Learning tasks are seen as pivotal in the interaction between teachers and learners. They provide one of many routes through which teachers and learners show attitudes and beliefs about the learning process to each other, as well as providing a vehicle within which the learning takes place.

At the beginning of each lesson, the teacher should assign the explicit learning tasks to the students. Recent investigations illustrate the significance of explicit knowledge as well as explicit learning conditions in classroom task designing. As a result, consciousness - raising activities have grown up to be an important teaching choice in foreign language teaching. Also, the learning tasks should be graded according to their difficulty level.

Apart from the learning tasks, teachers should set suitable learning goals for their students as well. And these goals could be divided into long-term ones and short - term ones so that they will be achievable for them. Moreover these goals should be set neither too high nor too low. On the one hand, if the goals are set too high, the students will lose confidence in achieving them. On the other hand, if the goals are set too low, the students will throw their interest away owing to the easy fulfillment.

\subsection{Career Design}

To be a responsible BE teacher, he/she is subject to assist the students in their career development and give them necessary instructions, while for the students, they must be clear about their career orientations whether their interests are available to the market or not.

\subsection{Effective Input}

It is necessary to provide meaningful input which will engage learners in working with Business English at a level which is slightly above their competence.

Related to the notion of input is that of output. Swain (1985) has put forward the comprehensible output hypotheses to emphasize the role of learner output in promoting acquisition. We can borrow this idea to apply it to the BE teaching with some adjustment. Using all the language and business resources they have already acquired, learners will test hypotheses and refine their developing knowledge of the BE system by getting feedback from the teacher and from other learners in the class. Simultaneously, learners are obliged to cope with their lack of language and business knowledge by struggling to make themselves understood, by speaking slowly, repeating or clarifying their ideas through 
paraphrasing. When a group of learners do this while talking together, it is called negotiation of meaning with the aim to make their output more comprehensible.

\section{Learner-centered Course Design}

\subsection{Be clear about the students' needs}

As a responsible teacher, before the course design, he/she should be clear about the students' needs or the designed courses will be invalid. During the 1970s, needs analysis procedures make their appearance in language planning related to the course design.

Richterich divides learning needs into two types: objective and subjective needs (Richterich, R., 1972). The former can be diagnosed by teachers on the basis of the analysis of personal data about learners along with information about their language proficiency and patterns of language use by means of questionnaires, interview, etc. The latter, however, include motivations, expectations, etc., which are difficult to get through a direct method. There is a tendency that objective needs are equal to specification of content and subjective needs are derived from the methodology. The dimensions themselves, however, are represented as a series of graduations rather than discrete categories.

\subsection{The content of course design}

Generally speaking, we can integrate the language and business knowledge and skills together, that is to say, to teach marketing, management and business know-how in English and select business - related materials for English teaching. More importantly, different teaching emphases should be selected according to different learning phases. At the beginning phase, the emphasis should be put to the integrative teaching of language and business knowledge. Then at the intermediate phase, the emphasis is subject to be turned to the teaching of language and various business--related skills. While moving to the advanced phase, the students should be given more chances to exercise their knowledge and skills in a business context, including the presentations, meetings, phoning, negotiating, email and report writing.

At the International Conference on Business English Studies 2008, Mr. Nick Brieger has proposed that the emerging trends of Business English is to focus on competence to bolt on to communication skills, reflecting changing global working patterns, thus the content of BE course design should often be adjusted to meet the changeable focuses and needs according to the economic development.

\subsection{The assistance of multimedia technology}

The application of CALL (computer assisted language learning) has provided for the English teaching with a new way of thinking.

Multimedia technology provides the learner with various ways of learning Business English from real-life situations. Learners are given multiple points of access to the same material and multiple potential paths through the material. For example, a business negotiation in English can be viewed at normal speed, as a native speaker would. It can be interrupted at any point with click of the mouse on a particular word or phrase. Learners can explore the material at their own level of proficiency, understanding and interest.

With the aid of computer, abundant teaching resources, ranging from business correspondence, advertisements, memos, minutes to the reports, recommendations, press release and business contracts in English, can be illustrated explicitly by means of powerpoint, which can assist the students to enhance their business knowledge and train their operational skills in a simulative environment so that their language and business knowledge and skills will be integrated much better gradually.

In a word, the advances in multimedia technology afford a type of learning that replicates non — pedagogical ways of acquiring knowledge and learning pursued in this way is exploratory and learner-driven, which are dramatically different from traditional textbook learning.

\section{The necessity of teaching methodology}

There is always an argument that without any knowledge of theories or principles of teaching, one might be able to teach a language based on his or her experience or intuitive sense of direction as well. However, teaching based only on personal experience and minimal practical skills will not go too far. Widdowson comments that "teachers tend to be referred as if they were factory workers to be provided with minimal practical skills and required to pick up on the job whatever extra expertise is necessary to keep the production line going." To reach standards of professionalism depends much on "a continual process of self-education through an evaluation of practice in reference to theory." (Widdowson, 1990)

One who knows a language well does not necessarily mean that he or she can teach that language well. We find that teaching and learning are bi-directionally interacting; teaching theory and teaching practice are mutually enhancing. On the one hand, experience, experimentation and observation in real-time teaching activities help to shape language teaching theories. On the other hand, these theories will in reverse act on instructional practice. Besides, 
interdisciplinary knowledge (e.g. psychology, sociology, pedagogy, management science) assists in language teaching. (Liu Yumei, Xiao Su, 2007)

During the development of the FLT approaches, so many important methods and approaches have been proposed, like the grammar-translation method, the direct method, the audio-lingual approach, the silent way, the suggestopedia, the community language learning, the total physical response, the cognitive approach, the communicative approach, the task-based language teaching, the learner-centered education and the postmethod pedagogy, etc. And each approach or methodology has played an active role in different teaching contexts during different periods in the course of development.

Since there are so many methodologies for foreign language teaching, we can borrow and absorb those excellent ones which are beneficial to us as well. On our way of searching for teaching methodology for BE teaching. No matter what approach is, since students differ greatly, not just in age but also in mentality, an effective teacher should constantly revise, vary, and modify the approaches listed below on the basis of the performance of the learners and their reactions to instructional practice. A group of teachers holding similar beliefs about the approaches may each implement these principles in different ways. (Richards \& Rodgers, 1986)

Among those ideas, the postmethod pedagogy is one of them. And it was first proposed by Canadian language education experts Stern (1983-1992). And some macro strategies of this pedagogy is of great value in both theory and practice to the $\mathrm{BE}$ teaching in China, that is, contextualizing linguistic input and integrating language skills, which are some strategies of the EFL (English as a Foreign Language ) teaching methodology (Stern, H., 2003). In order to absorb those strategies into our $\mathrm{BE}$ teaching practice, some adjustments have to be made, i.e. to change the two strategies into contextualizing Business English input and integrating both language and business skills and then to apply them into our teaching practice in different teaching models. Apart from the two strategies, some other principles of this pedagogy are also quite useful for the BE teaching, that is, to stimulate students to explore further by intuition, to promote interactional exchange between teachers and students or among students, to encourage students to do self - study, to keep up with the development of society, and to enhance students' sense of culture, etc. And we can use several teaching models to practice those methodologies such as lecturing, presentation, discussion and group work, seminar, case study, and practice in simulated business context, etc.

\section{Conclusion}

Business English is not a kind of science, but a response to market needs. It will go where demand takes it. At present, great market niche for BE talents still exists or is even increasing. However, the fact is that the training of BE talents is far behind the market need, which will propose an urgent task for the universities or colleges to try their best to improve their BE teaching. Successful BE teaching relies on not only the teachers' qualifications and their course designs, but also the teaching models and methodologies. Both knowledge and skills are required for a BE talent, so the integrative nature of BE teaching is the knowledge and skills. In order to meet the market need for BE talents with profound language and business knowledge and skills, we still have a long way to go.

\section{References}

Dickinson, L. (1981). English language teaching journal. [S.L.] [S.N.].

Guo, Guihang. (2008). Cultivation Modes of International Multi-skilled Talents: with the International Business Major as an Example. Contemporary Economics.

Richterich, R. (1972). A Model for the Definition of Language Needs. Strasbourg: Council of Europe.

Skehan, P. (2002). A Cognitive Approach to Language Learning. Shanghai: Shanghai Foreign Language Education Press.

Stern, H. (2003). Fundamental Concepts of Language Teaching. Shanghai: Shanghai Foreign Language Education Press.

Widdowson, H. (1990). Aspects of Language Teaching. Oxford: Oxford University Press.

Zhao, Fang. (2008). Research on the Curriculum Design of Business English Major. Shanxi Technology. 